\title{
Spectacle and adventure philanthropy
}

While humanitarian tourism is increasingly examined from critical theory perspectives (see Ingram, 2011; Mostafanezhad, 2013, 2104; Simpson, 2004), less attention has been given to the role of media and spectacle in the enactment of this type of tourism. This research note aims to expose the social power of spectacle in humanitarian tourism, broadly, by arguing that the production of spectacle is necessary to adventure philanthropy, specifically. Adventure philanthropy combines altruism and humanitarianism with adventure travel (Lyons \& Wearing, 2008) and is part of broader trends in philanthropy that employ alternative means of fundraising (Coghlan \& Filo, 2013; Goodwin, McCombes, \& Eckardt, 2009). In adventure philanthropy, individuals partner with charitable organizations to set travel goals while engaging social media to raise awareness and funds for specific causes - for example, trekking the Silk Road to raise funds for women's health initiatives or kayaking to Guatemala to support children's education in the country. However, the spectacle of travelling towards destinations where aid recipients wait commodifies both the recipients' poverty and the philanthropists' adventure stories. This effect, in turn, depoliticizes the structural causes of poverty, ultimately normalizing inequality and reproducing the status quo, which raises questions as to the effectiveness and the results of humanitarian tourism. Such questions are relevant to a number of stakeholders: tourists/participants, audiences, recipient communities, corporate sponsors, and humanitarian organizations.

Debord's theory of the society of the spectacle is most known for the contention that "spectacular society effaces the reality of class struggle" (Jenkins, 2009, p.8). The totalizing effects of commodification have transformed social life from being to having to appearing (Debord, 2009, p. 28). The spectacle "is not a collection of images; it is a social relation between people that is mediated by images" (Debord, 2009, p. 24). As such, spectacle is commonly used to explain visual ideologies of tourism, in particular the "tourist gaze" (Ryan, Hughes, \& Chirgwin, 2000; Yudina \& Grimwood, 2016) and tourism marketing (Cloke \& Perkins, 2002; Gotham, 2002). However, Lisle (2004) extends the implications of spectacle by suggesting that 
many tourists are well aware that "the world is mediated and commodified for their consumption" (p. 14-15). Indeed, Linhart's (2006) analysis of mission trips observed students who are critical of the spectacle nature of the trip, while also aware of their own inability to overcome it. The spectacle society "created an existence against which the students want to feel"; they wanted "to act passionately" and "to reach out and to help others" (p. 456-7). Nevertheless, they reproduced the spectacular images that inspired their participation in the trip. This is the power of spectacle, argues Jenkins (2009); it is both the means and the end of action, continually reproducing itself, because "[i]n the name of either 'enlightened pragmatism' or a pernicious moralism the pseudo-choices we are presented with come with an impossible burden of 'responsibility' for their consequences" (p.18). Thus, we posit that in order to garner public attention, spread awareness, and raise funds spectacle is a necessary condition of adventure philanthropy. Yet, the power of spectacle is not uniform but rather extends from four social functions: burden of responsibility, enlightened pragmatism, spectacular rebelliousness, and celebrity, each of which turns attention away from aid recipients and towards the adventurers thereby commodifying the event. As such, Debord's theory of the society of spectacle should be reconsidered for its applicability to humanitarian tourism and the role of media within it.

\section{Burden of responsibility}

Adventure philanthropy events are ultimately about enduring the challenge of a long-distance journey as an act of solidarity with those who are "in need". Thus, like many humanitarians, adventure philanthropists are motivated by a sense of responsibility, that they can personally make a difference and implore others to do the same (Wearing, 2001; Butcher \& Smith, 2015). However, such events perpetuate many of the criticisms inherent in broader humanitarian ideologies that incorporate notions of development and cater to a "desire for intimacy and a private route into social issues" (Butcher \& Smith, 2015, p. 69; see also Conran, 2011). Thus, Mostafanezhad (2014) highlights the connections between humanitarian tourism and Zizek's (2009) notion of "consumer redemption", revealing the relationality of touristic consumption to depoliticizing geopolitical discourses. 
In adventure philanthropy, the adventurers' narratives demonstrate a coalescence of the themes of hard work, persistence, and overcoming obstacles that apply to both themselves and the aid recipients. Because spectacle is the "opposite of dialogue", Debord argues, it "depicts what society could deliver but in so doing it rigidly separates what is possible from what is permitted" (2009, p. 31). Thus, the adventurers accept the burden of responsibility for making a difference and take action, while the recipients are presented with the impossibility of following their example.

\section{Enlightened pragmatism}

As a part of taking action for a humanitarian cause, adventure philanthropists partner with a charitable organization to elevate their impact. As spectacle loses its power if there is no audience, they employ various media to expand their audience - social media, blogs, and photostreams, along with local news reports and GPS tracking - to present "real time" accounts. Additionally, many also acquire corporate sponsors. Thus, engagement with media in the production of spectacle is necessary for evidencing the adventurers' ability to deliver visibility to their sponsors, as well as raising funds.

In the spectacle society, "commodification is not only visible, we no longer see anything else" (Debord, 2009, p. 39). In order to draw an audience, media representations foreground personal journeys, while the specific charitable causes are often pushed to the background. So while spectacle maintains an audience, it also serves to depoliticize. Such apolitical approaches to deeply political issues parallels criticisms of development strategies, more broadly, and volunteer tourism, more specifically, in which "[h]ost communities are passive in the equation [...] in desperate need of the volunteers' assistance" (Ingram, 2011, p. 219). Such portrayals, Simpson argues, are necessary for the promotion of volunteer tourism's "public face of development" which "comprises simplistic, consumable and ultimately 'do-able' notions of development" (2004, p. 690). 


\section{Spectacular rebelliousness}

A key to successful media engagement is the spectacularity of the adventure. Because much of the world demonstrates a "complacent acceptance of the status quo", Debord (2009) suggests that "dissatisfaction itself becomes a commodity" that can be leveraged as "spectacular rebelliousness" (p. 48). For adventure philanthropists even the means of travel is crucial to the production of spectacle, as alternative mobilities are interpreted as liberating, antifoundational, and transgressive (Cresswell, 2010). Choosing a unique mode of transport, therefore, sets individuals apart from the crowd of other humanitarians and initiates an adventure story. Thus, combining the altruism and empathy of humanitarian tourism with the ideologies of rebelliousness, individualism, and freedom presents an opportunity for self-image enhancement and expression of values that both challenges the status quo (Arai \& Pedlar, 2003; Bekkers \& Wiepking, 2007; Coghlan \& Filo, 2013) and acquires social status (Canavan, 2017). Yet, the production of spectacle ultimately commodifies their journeys, arguably maintaining the status quo.

\section{Celebrity}

In adventure philanthropy, arrival at the destination is the culmination of the spectacle event. It assuages audience concerns for the safety of the adventurers and offers proof that those "in need" exist, while practices of gratitude authenticate the adventurers as humanitarians. In these final moments of the spectacle the roles of the "host" and "guest" reverse, as those who were previously thought of as guests become hosts in the production of spectacle (MacDonald, 2002, p. 71). The charitable organization, along with the adventurers, implore the local resident and aid recipient to partake in the spectacle and to be a "guest" in their performance of humanitarianism.

The social media success of some adventure philanthropists, coupled with celebrations as they arrive at their destinations, evokes a kind of celebrity status (see Mostafanezhad, 2013). Debord conceptualizes celebrities as "spectacular representations of living human beings" whose function is to "act out various lifestyles or sociopolitical viewpoints in a full, totally free 
manner" (2009, p. 48). That many adventure philanthropists are further recognized, with awards and honors from other adventure societies and development organizations, suggests that spectacular rebelliousness extends the power of celebrity well beyond the journey itself.

In conclusion, this note aims to expose the social power of spectacle in humanitarianism by arguing that in adventure philanthropy the production of spectacle is necessary. As an alternative means of spreading awareness and raising funds, these endurance events must be broadcast, blogged, and shared. As long as spectacular rebelliousness holds purchase in society, then perceptions of the burden of responsibility coupled with a desire for a private route into social issues (see Butcher \& Smith, 2015; Conran, 2011) will be met with approaches to humanitarianism that operate within the spectacle society, including engaging media representations and fanning celebrity status (see Mostafanezhad, 2013). While alternative approaches to raising awareness suggest a kind of enlightened pragmatism, the power of their spectacles can also be observed in the ways they affirm appearances (Debord, 2009, p. 26-28), naturalizing the inequalities that inspire such humanitarian endeavors. As a result, our interrogations of humanitarian tourism should extend to the ways media is employed and integrated into the social function of the event. Debord's theory of the spectacle remains an undervalued perspective for initiating these investigations.

\section{References:}

Arai, S. \& Pedlar, A. (2003) Moving beyond individualism in leisure theory: A critical analysis of concepts of community and social engagement. Leisure Studies, 22(3), 185-202.

Bekkers, R., \& Wiepking, P. (2007). Generosity and philanthropy. A literature review. Utrecht: University of Utrecht, ICS.

Butcher, J. \& Smith, P. (2015). Volunteer Tourism: The lifestyle politics of international development. London: Routledge. 
Canavan, B. (2017). Narcissism normalisation: tourism influences and sustainability implications. Journal of Sustainable Tourism, 25(9), 1322-1337.

Cloke, P., \& Perkins, H. C. (2002). Commodification and Adventure in New Zealand Tourism. Current Issues in Tourism, 5(6), 521-549.

Coghlan, A. \& Filo, K. (2013) Using constant comparison method and qualitative data to understand participants' experiences at the nexus of tourism, sport and charity events. Tourism Management, 35(1), 122-131.

Conran, M., 2011. "They Really Love Me!": intimacy in volunteer tourism. Annals of Tourism Research, 38(4), 1454-1473.

Cresswell, T. (2010). Towards a politics of mobility. Environment and Planning D: Society and Space, 28(1), 17-31.

Debord, G. (2009). Society of the Spectacle. Sussex: Soul Bay Press Ltd.

Goodwin, H., McCombes, L. \& Eckardt, C. (2009) Advances in travel philanthropy: Raising money through the travel and tourism industry for charitable purposes. WTM Responsible Tourism Day (Report 2). Available at www.icrtourism.org/documents/2_nov_wtm_tp_final_report. pdf (accessed 27 March 2012).

Gotham, K. F. (2002). Marketing Mardi Gras: Commodification, spectacle and the political economy of tourism in New Orleans. Urban Studies, 39(10), 1735-1756. 
Ingram, J. (2011). Volunteer tourism: how do we know it is 'making a difference'? In A.M. Benson (Ed.), Volunteer Tourism: Theoretical frameworks and practical applications, (pp. 211-222). Abingdon, Oxon: Routledge.

Jenkins, M. (2009). Introduction The Society of Spectacle (pp. 4-19). Sussex: Soul Bay Press Ltd.

Linhart, T. D. (2006). They were so alive!: The spectacle self and youth group short-term mission trips. Missiology: An International Review, XXXIV(4), 451-462.

Lisle, D. (2004). Gazing at Ground Zero: Tourism, voyeurism and spectacle. Journal for Cultural Research, 8(1), 3-21.

Lyons, K., \& Wearing, S. (2008). All for a good cause? The blurred boundaries between volunteering and tourism. In K. Lyons, \& S. Wearing (Eds.), Journeys of discovery in volunteer tourism (pp. 147-154). Wallingford: CAB International.

MacDonald, F. (2002). The Scottish Highlands as Spectacle. In S. Coleman \& M. Crang (Eds.), Tourism: Between place and performance (pp. 54-73). New York: Berghahn Books.

Mostafanezhad, M. (2013). 'Getting in touch with your inner Angelina': Celebrity humanitarianism and the cultural politics of gendered generosity in volunteer tourism. Third World Quarterly, 34(3), 485-499.

Mostafanezhad, M. (2014). Volunteer tourism and the popular humanitarian gaze. Geoforum, 54(1), 111-118.

Ryan, C., Hughes, K., \& Chirgwin, S. (2000). The gaze, spectacle and ecotourism. Annals of Tourism Research, 27(1), 148-163. 
Simpson, K. (2004). 'Doing development': the gap year, volunteer-tourists and a popular practice of development. Journal of International Development, 16(5), 681-692.

Wearing, S. (2001). Volunteer tourism: Experiences that make a difference. Cabi.

Yudina, O., \& Grimwood, B. S. R. (2016). Situating the wildlife spectacle: Ecofeminism, representation, and polar bear tourism. Journal of Sustainable Tourism, 24(5), 715-734.

Zizek, S., 2009. First as Tragedy, then as Farce. London: Verso. 